\title{
DNA CONTENT OF HUMAN SPERMATOZOA AFTER STORAGE AT LOW TEMPERATURES
}

\author{
D. R. AGKERMAN AND U. A. SOD-MORIAH* \\ Center for Research in Reproductive Biology, University of Michigan Medical Center, \\ Ann Arbor, Michigan
}

(Received 16th August 1967)

\begin{abstract}
Summary. Glycerolated semen specimens of several donors were examined for DNA content after refrigeration at $+6^{\circ} \mathrm{C}$ for 7 days, and after storage in liquid nitrogen for periods ranging from 2 to 75 weeks. Fresh specimens were also studied. DNA determinations were made in each case by both Feulgen microspectrophotometry (in arbitrary units) and by the Webb-Levy chemical determination. The quantity of DNA per cell in arbitrary units and in $\mathrm{mg} \times 10^{-9}$ remained constant after refrigeration, and after freezing-preservation for all time periods studied. Discrepancies between the two kinds of determination, and the concept of embryonic mortality due to aged spermatozoa are discussed.
\end{abstract}

\section{INTRODUGTION}

Evidence showing that the nuclear deoxyribonucleic acid (DNA) content of mature spermatozoa remains constant has not been seriously questioned except in two instances. Salisbury, Birge, De La Torre \& Lodge (1961) reported that bovine sperm stored at $5^{\circ} \mathrm{C}$ for 10 days showed a progressive decrease in Feulgen-positive material, amounting to $30 \%$ by the 5 th day. Chang (1959) found, also by means of Feulgen staining, that rabbit spermatozoa recovered from the female reproductive tract after insemination contained more DNA than freshly ejaculated spermatozoa.

Two interpretations have been offered for these findings. It is suggested that quantitative assessments of the intensity of the Feulgen reaction are difficult to reproduce (Welch, Hanly \& Guest, 1961) and that variations in absorbance are due to factors other than absolute differences in DNA content of the cells. Alternatively, Mann (1964) has pointed out that it would be unwise to reject the possibility of nucleic acid increases or decreases in mature spermatozoa. Human seminal plasma contains nucleases (Zamenhof, Shettles \& Chargaff, 1950). A nucleotide-transferring enzyme (polynucleotide phosphorylase), capable of synthesizing polymers of various nucleotides, has been demonstrated in human spermatozoa (Hakim, 1959). There are not firm grounds for the expectation that DNA content will decrease or increase in mature sperm cells, but it is appropriate to investigate the possibility that such changes could occur under particular circumstances.

\footnotetext{
* Present address: The Negev Institute for Arid-Zone Research, Beer Sheva, Israel.
} 
Salisbury (1960) was of the opinion that the decreased fertilizing capacity of stored bovine spermatozoa might be due to changes in cellular DNA content. The decline in fertility of frozen-preserved human specimens is considered to be serious enough to warrant investigation of this hypothesis, in addition to others. There appear to be no studies in the literature on the effect of freezing and subsequent long term storage upon the DNA content of any mammalian spermatozoa.

\section{MATERIALS AND METHODS}

Semen specimens were obtained from seven individuals, usually twice monthly, for periods of 5 to 12 months. All specimens were considered to be normal, except one which consistently displayed a high percentage of cells designated as 'tapering' (MacLeod, 1964). Specimens of two of these donors had previously produced pregnancies after freezing-preservation, while those of the rest had not; specimens of all these donors had been used repeatedly for purposes of insemination after freezing-preservation.

Each specimen was mixed $1: 1 \mathrm{v} / \mathrm{v}$ with a conventional yolk-glycerol-citrate medium, partitioned into $1 \cdot 2-\mathrm{ml}$ glass ampules, and cooled to storage temperature by standard methods (Sawada \& Ackerman, 1968). Most of these specimens were stored in liquid nitrogen; some were placed in a mechanical freezer at $-96^{\circ}$ G. These collections were continued until a number of specimens, varying in age from 1 to 14 months, was available from the several donors.

Before beginning the study of the stored specimens, each of the donors still available provided at least one additional semen specimen. These specimens were mixed with preservative medium and divided into two parts; one part was prepared for immediate analysis of DNA content without further treatment, while the second portion was refrigerated for 7 days at $+6^{\circ} \mathrm{C}$ in a stoppered tube and was subsequently processed for the study.

Each specimen was assayed for DNA content in two ways. The Feulgenstaining method was selected in order to provide data comparable to those of Salisbury et al. (1961). The possibility that the prior treatment of the cells might influence the Feulgen reaction, or that the technique itself might be subject to artifacts was met by the introduction of a second method of DNA determination. The colorimetric technique of Webb \& Levy (1955) was used for this purpose.

Six to eight specimens were processed simultaneously. Two millilitres of each specimen were thawed at room temperature, pooled and counted by the haemocytometer method. Two smears of each specimen were made on glass slides and air dried for Feulgen processing. Each was then divided into two $1 \cdot 0-\mathrm{ml}$ aliquots, so that duplicate assays could be provided in every case, and the specimens were assayed by the Webb-Levy method. Standards of 10, 25, 50, 75 and $100 \mu \mathrm{g}$ were prepared from highly polymerized calf thymus DNA (Sigma Chemical Company, St Louis, Missouri) and provided for each set of assays.

When semen smears from all specimens were available, these were processed for the Feulgen reaction in five separate lots. The slides were washed in two changes of xylene for 15 min each, and carried through 95, 80, 70 and $50 \%$ 
alcohol washes for $5 \mathrm{~min}$ each. After $5 \mathrm{~min}$ in $30 \%$ alcohol at $60^{\circ} \mathrm{C}$, the slides were rinsed in $1 \mathrm{~N}-\mathrm{HCl}$ at $60^{\circ} \mathrm{C}$.

Preliminary experiments were conducted to determine the optimal hydrolysis time. The intensity of the Feulgen reaction was compared after hydrolysis of $5 \cdot 0,7 \cdot 5,10 \cdot 0,12.5$ and $15 \cdot 0$ min of ten semen smears in each case, all smears having been made from the same glycerolated semen specimen. Variance analysis indicated that hydrolysis for 12.5 or 15.0 min gave a quantitatively better reaction than $5.0 \mathrm{~min}$ hydrolysis; $12.5 \mathrm{~min}$ was selected as optional. The experimental slides were hydrolysed in $1 \mathrm{~N}-\mathrm{HCl}$ at $60^{\circ} \mathrm{C}$ in a thermostatically controlled water bath. Feulgen solutions and staining procedure were those detailed by Leuchtenberger (1958). The slides were mounted in diaphane.

Transmittance measurements were made on a Leitz microspectrophotometer, using a Bausch and Lomb monochromator and a Photovolt densitometer. Monochromator entrance and exit slits were $1 \mathrm{~mm}$; plug size was 5 units, and transmittance readings were made at $560 \mathrm{~m} \mu$. Readings were taken from the centre of the sperm head. The greatest length and greatest breadth of each cell was recorded by means of the eyepiece micrometer, in arbitrary units. Measurements and transmittance readings were made for ten cells on each slide, i.e. twenty cells for each specimen studied.

The amount of stained material in each cell was calculated in arbitrary units. The convention was adopted that the human sperm head is ellipsoid in its geometry when it presents its greatest breadth to the observer. The area of each cell was determined as $A=\pi a b$, where $a$ and $b$ are one-half the greatest length and greatest breadth, respectively. This value was multiplied by the $\log$ of the ratio $t_{c} / t_{n}$, where $t_{n}$ is the transmittance of the cell and $t_{c}$ is the transmittance of the background immediately adjacent to that cell.

\section{RESULTS}

Tables 1 and 2 give means and standard errors for specimens in each category of storage time. Results are expressed in arbitrary units for the Feulgen-stained specimens, and in $\mathrm{mg} \times 10^{-9} / \mathrm{cell}$ for the aliquots extracted by the method of Webb \& Levy (1955).

Analysis of variance, applied to the results in Tables 1 and 2, shows no differences in DNA content of sperm cells in any category of storage time. DNA content of the fresh and refrigerated specimens does not differ, nor does that of either differ from any of the four categories of frozen-preserved specimens.

Although the two methods of quantitating the DNA content of the cells give the same result with respect to storage time, there are clearly differences between them. No correlation exists between arbitrary unit and milligram values obtained for each specimen: $r=-0.237, F_{1,33}=1.95$. This relationship, while not significant, tends to be negative as would be expected.

Comparisons between donors in all categories of frozen-preserved specimens also indicate differences between the extraction and the Feulgen methods. Milligram means for donors vary from $1.38 \times 10^{-9}$ to $3.29 \times 10^{-9} \mathrm{mg} /$ cell, with an overall mean of $2.31 \times 10^{-9} \mathrm{mg} /$ cell. These results by the technique of Webb and Levy are similar to those of White, Leslie \& Davidson (1953), by 


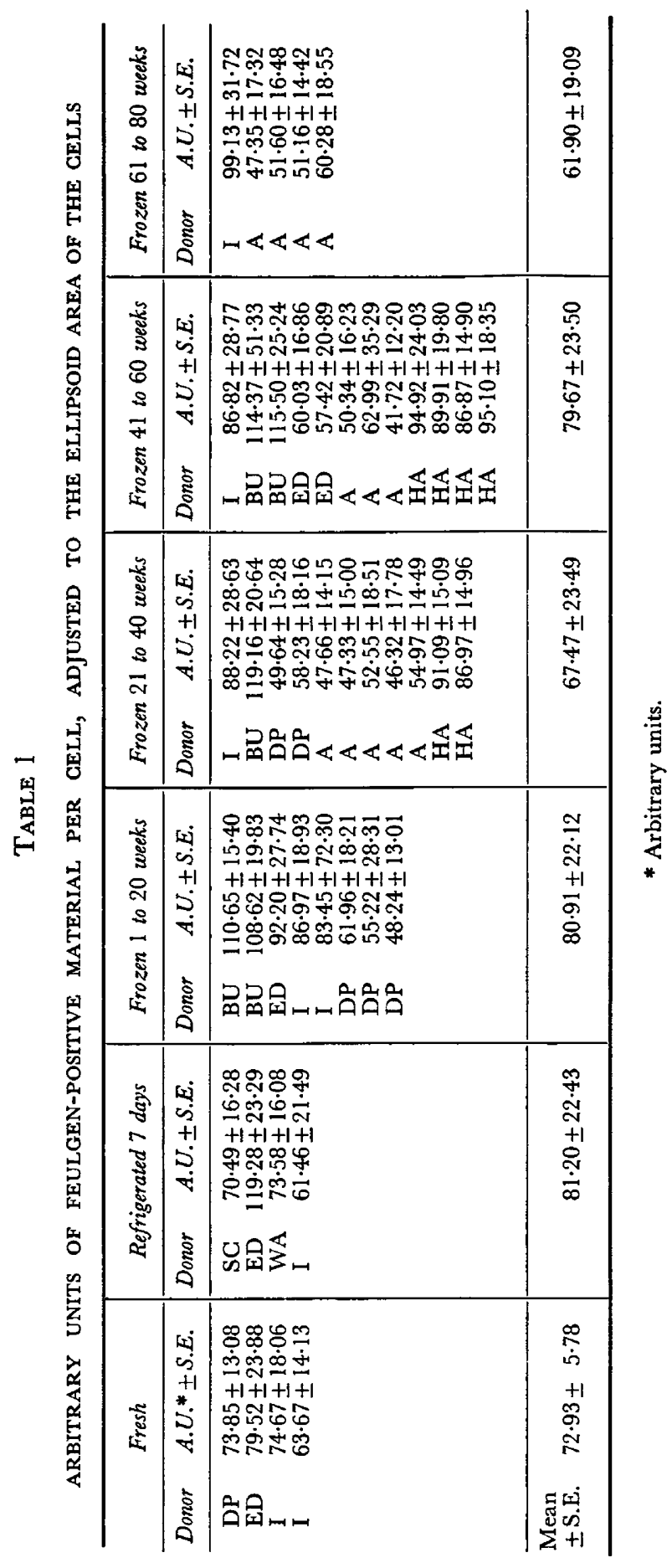




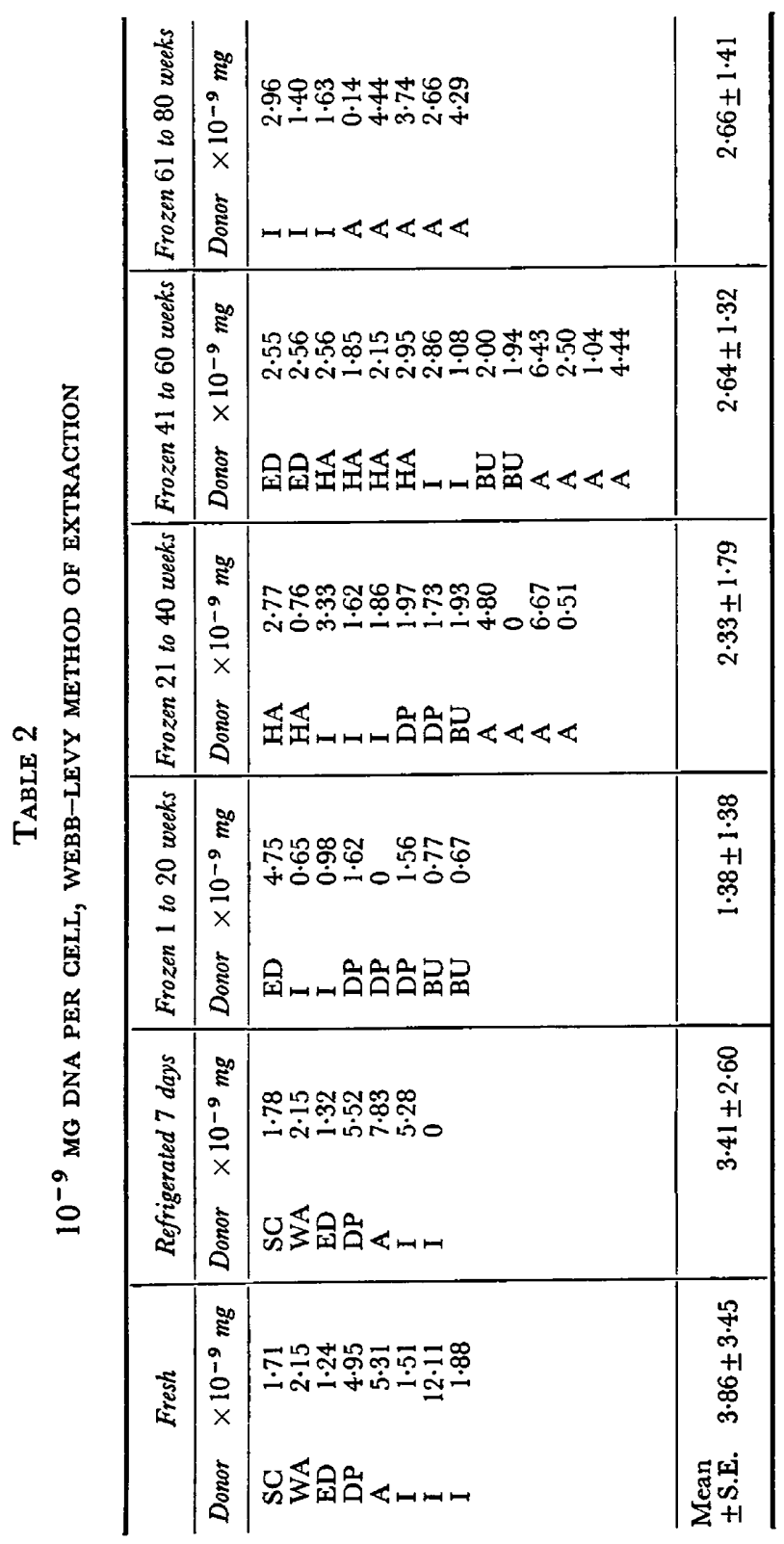


DNAP analysis and of Leuchtenberger, Leuchtenberger, Schrader \& Weir (1956) by Feulgen microspectrophotometry. There are no significant differences among donors in $\mathrm{mg} \mathrm{DNA} \times 10^{-9} /$ cell. There are, however, differences between donor means for arbitrary units of Feulgen-positive material; $F_{5,29}=$ $68.55,0.001>P$. The various differences between donors revealed in this analysis by Tukey's test are not apparently related to the known fertility or infertility of the donors. No correlation exists between storage time and arbitrary units or milligram values, for the specimens of individual donors.

\section{DISCUSSION}

It is clear that the DNA content of human spermatozoa remains constant after refrigeration for 1 week at $+6^{\circ} \mathrm{C}$, and for periods ranging from 2 to 75 weeks at ultra-low temperatures. The mean milligram values of DNA in cells so preserved $\left(2.25 \times 10^{-9} \mathrm{mg} / \mathrm{cell}\right)$, obtained by the Webb-Levy method, do not differ from the values obtained for fresh cells. The grand mean, $2.66 \times 10^{-9}$ $\mathrm{mg} / \mathrm{cell}$, is not different from the values obtained for fresh cells by White et al. (1953) and Leuchtenberger et al. (1956), which are 3.14 and $2.46 \times 10^{-9}$ $\mathrm{mg} /$ cell, respectively.

This finding is reassuring from the clinical viewpoint, since the practice of using frozen-preserved semen for donor insemination is rapidly gaining currency in infertility clinics. These results also support the concept of spermatozoan DNA constancy under conditions of ageing, temperature shock, freezing, longterm storage and thawing.

The fact that frozen-preserved human spermatozoa do exhibit significantly lowered fertilizing capacity (Behrman \& Sawada, 1966) is undoubtedly associated with altered cellular metabolism (Sawada \& Ackerman, 1968; Ackerman, 1967, 1968). The difficulty does not, however, appear to be any function of faulty transmission of hereditary material in the spermatozoa. Salisbury et al. (1961) endorsed the latter possibility in part on the basis of their finding that the use of aged bovine spermatozoa resulted in an apparent increase in early embryonic mortality (Salisbury, Bratton \& Foote, 1952). The records of human inseminations maintained by the Genter for Research in Reproductive Biology at the University of Michigan do not indicate that aged spermatozoa are implicated in any way in spontaneous abortions. In fact, abortions have occurred only in some cases in which the patient has a history of early abortion before insemination with frozen-preserved donor specimens.

Of particular interest is the occurrence of discrepancies between the two methods used to quantitate cellular DNA. The Feulgen and Webb-Levy techniques are in agreement with respect to the constancy of cellular DNA over time. However, the former method indicates significant mean differences between donors, while the chemical determination does not.

The computation of arbitrary units of Feulgen-positive material is based upon both cell size and cell transmittance. Each of these was analysed separately in an attempt to discover the source of the discrepancy. In particular, it was necessary to examine the possibility that a constant amount of DNA would be less densely distributed in larger cells. Both size, $F_{5,30}=9.31,0.001>P$, and 
transmittance, $F_{5,30}=84 \cdot 79,0.001>P$, varied significantly among donors. But there is no correlation between these parameters; $r=0.04, F_{1,31}=0.05$. Leuchtenberger (1958) points out that error due to non-homogeneous distribution of absorbing nuclear material is greatest at the absorption peak, $546 \mathrm{~m} \mu$. It is possible that our results are, in some part, an artifact of this type of error.

There is no obvious explanation for this discrepancy between the methods. It does appear reasonable to suggest that there is some value in using an independent assay in addition to the Feulgen method when cellular DNA is studied. This is particularly true when prior treatment of the cells could produce effects which might alter the Feulgen reaction.

\section{ACKNOWLEDGMENT}

\section{Supported by Grant 07950 NIH HD 01077-02 and Ford Foundation Grant 37482.}

\section{REFERENCES}

Ackerman, D. R. (1967) Fructose utilization of human spermatozoa after cooling and freezing. Int. 7. Fert. 12, 1 .

ACKERMan, D. R. (1968) The effect of cooling and freezing on the aerobic and anaerobic lactic acid production of human semen. Fert. Steril. 19, 123.

Behrman, S. J. \& Sawada, Y. (1966) Heterologous and homologous inseminations with human semen frozen and stored in a liquid-nitrogen refrigerator. Fert. Steril. 17, 457.

Chang, M. C. (1959) Fertilizing capacity of spermatozoa. In: Recent Progress in the Endocrinology of Reproduction, p. 131. Ed. C. W. Lloyd. Academic Press, New York.

Hakrm, A. A. (1959) Synthetic activity of polynucleotide phosphorylase from sperm. Nature, Lond. 183, 334.

LEUCHTENBERGER, C. (1958) Quantitative determination of DNA in cells by Feulgen microspectrophotometry. In: General Cytochemical Methods, vol. 1, p. 219. Ed. J. F. Danielli. Academic Press, New York.

Leuchtenberger, C., Leuchtenberger, R., Schrader, F. \& Weir, D. (1956) Reduced amounts of desoxyribose nucleic acid in testicular germ cells of infertile men with active spermatogenesis. Lab. Invest. 5, 422.

MacLeod, J. (1964) Human seminal cytology as a sensitive indicator of the germinal epithelium. Int. $\mathcal{F}$. Fert. 9, 281.

MANN, T. (1964) The biochemistry of semen and of the male reproductive tract, p. 152. Wiley, New York.

Salisbury, G. W. (1960) Published discussion following paper by C. Leuchtenberger. f. Dairy Sci. 43 (Suppl.), 50.

Salisbury, G. W., Birge, W., De La Torre, L. \& Lodge, J. (1961) Decrease in nuclear Feulgen-positive material (DNA) upon aging in in-vitro storage of bovine spermatozoa. $\mathcal{F}$. biophys. biochem. Cytol. $10,353$.

Salisbury, G. W., Bratton, R. W. \& Foote, R. H. (1952) The bull as one cause of delayed returns to service in artificial breeding. 7. Dairy Sci. 35, 250.

Sawada, Y. \& Ackerman, D. R. (1968) Use of frozen human semen. In: Progress in Infertility. Ed. S. J. Behrman and R. W. Kistner. Little, Brown, Boston. (In press).

WEBB, J. M. \& LEVY, H. B. (1955) A sensitive method for the determination of deoxyribonucleic acid in tissues and microorganisms. F. biol. Chem. 213, 107.

Welch, R. M., HanLy, E. \& Guest, W. (1961) The experimental error of Feulgen cytophotometry in the analysis of bull spermatozoa over an extended period of time. F. Histochem. Cytochem. 9, 251.

White, J. C., Leslie, I. \& Davidson, J. (1953) Nucleic acids of bone marrow cells, with special reference to pernicious anaemia. 7. Path. Bact. 66, 291.

Zamenhof, S., Shetrles, L. \& Chargaff, E. (1950) Human desoxypentose nucleic acid. Nature, Lond. $165,756$. 